\title{
'THEY TELL ME THAT I CAN \\ WRITE AND READ, SO NO NEED FOR SCHOOL'
}

\section{Challenges in realising international commitments to refugee education in Jordan}

\author{
Agnieszka Małachowska, Nicola Jones and \\ Sarah Al Heiwidi
}

\section{Introduction}

With 25.9 million refugees around the world - more than half of them children and 7.1 million of school age (United Nations High Commissioner for Refugees (UNHCR), 2019a) - a key concern and challenge for host nations is providing education for refugees. In 2015, as part of the 2030 Agenda for Sustainable Development, United Nations (UN) members pledged to ensure 'inclusive and equitable quality education' and 'lifelong learning opportunities for all' (UNHCR, 2017b; United Nations General Assembly, 2015). The following year, in the New York Declaration for Refugees and Migrants, governments pledged to share responsibility for the world's refugees and to improve access to education for refugee children (United Nations General Assembly, 2016). Despite these declarations and commitments, there has been little change in practice for more than half of the world's 7.1 million refugee children who are still out of school (UNHCR, 2018).

The ongoing conflict in Syria, which started in 2011, has taken a heavy toll on young people's lives and their developmental trajectories. Education and learning have been particularly constrained. In Jordan, home to more than 650,000 Syrian refugees (UNHCR, 2019b), the government has opened up schools to Syrian children and adolescents, and donors and non-governmental organisations (NGOs) have invested heavily in scaling up formal and informal learning pathways. Yet enrolment rates remain low, especially for secondary and tertiary education. According to the Jordan 2017-2018 population and family health survey, while enrolment at basic primary level is almost universal, the net attendance ratio at secondary level is only 30 per cent for Syrians (31 per cent of girls vs. 29 per cent of boys), compared to 74 per cent for Jordanians (78 per cent of girls vs. 71 per cent of boys) (Department of Statistics and ICF, 2019). 
Barriers to education differ by gender: while boys often leave school due to poor quality of education, harsh corporal punishment by teachers and pressures to contribute to household income, girls drop out due to restrictive gender norms related to family honour, fears of sexual harassment on the way to school and the lack of value placed on girls' education in general. For adolescent girls who are married (or soon to be married), access to education is even more restricted. Moreover, learning outcomes for adolescents who are in school are unsatisfactory, especially for boys, and the school environment is not conducive to developing abilities that would go beyond core knowledge to provide twenty-first-century competencies and skills. Despite Jordan's efforts to increase overall enrolment since the beginning of the Syrian crisis, the results - in terms of increasing access for older adolescents, and particularly girls - are unsatisfactory. The development trajectories of out-ofschool adolescents are hindered across multiple dimensions, from voice and agency to economic empowerment, with longer-term consequences into adulthood and throughout the life course.

Unless efforts to reach those most left behind (including refugees) are intensified, Sustainable Development Goal (SDG) 4 will not be met (this is underscored by the SDG +5 progress review), and particularly Target 4.7 , which commits countries to ensuring that learners acquire knowledge and skills in areas such as sustainable development, human rights, gender equality and global citizenship (United Nations, 2020). Access to safe, quality and inclusive education in contexts of displacement is key to promoting adolescent wellbeing now and also to ensuring that refugee adolescents have opportunities to live fulfilled lives as adults.

This chapter focuses on the most vulnerable Syrian refugee adolescents living in Jordan, including girls married as children, working adolescents and those living in remote areas. Using a capabilities framing of the right to education, we examine barriers and gendered differences in access to education for refugee adolescents living in three distinct settings: host communities, informal tented settlements (ITSs) and refugee camps. Drawing on mixed-methods data collected in 2018 and 2019, we explore the interplay of geography, gender norms, individual and family aspirations, and community and system-level factors in shaping access to formal and nonformal education and learning, and the acquisition of academic and non-academic core competencies.

\section{Syrian refugee context in Jordan}

In 2012, ahead of the 2030 Agenda for Sustainable Development commitments and soon after the start of the Syrian conflict, the Jordanian government decided to extend formal education to Syrian refugee children in host communities and refugee camps. The Ministry of Education divided Syrian refugee children into three categories: Syrians in camps, Syrian students in regular schools alongside Jordanian students and Syrian students in afternoon classes (second shifts). However, while the government is formally committed to ensuring that 'all male and female Syrian refugee students enrol in kindergarten, primary and secondary education', enrolment 
rates at all levels remain low, but especially for secondary and tertiary education (Ministry of Education, 2018). In partnerships with international donors, the Jordanian government has prioritised rebuilding and renovating education infrastructure, rather than funding interventions targeting out-of-school adolescents (Human Rights Watch, 2020).

With no political solution to the Syrian conflict in sight, the challenges are manifold (UNICEF, 2019a; UNESCO, 2016). Barriers preventing Syrian adolescents from accessing education are widely cited in the literature and summarised in the following. First, the lack of registration documentation required to enrol was a major challenge, especially in the first years of the conflict, when many families were unable to obtain 'service cards' entitling them to access basic services, including public schools. ${ }^{1}$ Though efforts have been made to improve access and waive these requirements, many families were not aware of the changes and also reported that lack of identification documents remained a barrier to their children enrolling (Younes and Morrice, 2019). Second, many families fled Syria without bringing school and birth certification for their children, which created additional barriers (Human Rights Watch, 2016). Another barrier was caused by the Ministry's regulation barring school enrolment for children who are three or more years older than their grade (ibid.). Moreover, double-shift schools face many problems, such as overcrowding, lower standards and decreased resourcing for the afternoon shift (predominantly Syrian students), and violence in and around schools, which leads to dropouts. The low value placed on education among Syrian children and their families is another barrier (Culbertson at al., 2016; Human Rights Watch, 2016). Poverty among Syrian families and limited prospects of decent employment are further challenges, preventing them from being able to afford school-related costs, such as transport or study materials. It also pushes many families to rely on money earned by children (especially boys) through work, exacerbating the risks (for girls) of child marriage (UNHCR, 2017a; Culbertson at al., 2016; Abu Hamad et al., 2017). Long distances to schools (particularly for refugees living in remote ITS areas) and concerns about safety on the way to school, combined with very limited public transport options and families not being able to pay for private transport, further limit access to schooling (Abu Hamad et al., 2017).

Ensuring that children and adolescents attend school is only part of the challenge. Basic learning outcomes in Jordan, as measured by the OECD's Programme for International Student Assessment (PISA) test, are (despite a slight improvement in recent years) among the lowest of PISA countries - especially for boys (OECD, 2019). Although assessments by the Ministry of Education show that the quality of teaching is slowly improving, challenges remain, particularly in learning outcomes in formal education. For children in Grades 1-3, the Early Grade Reading and Mathematics Project (RAMP) assessment shows slow improvement in basic reading comprehension levels (up from 43 per cent in 2017 to 55 per cent in 2018), but progress for outcomes for basic mathematics skills is much slower (up from 28 per cent in 2017 to 30 per cent in 2018), with Syrian children performing worse than their Jordanian peers (RAMP, 2018; No Lost Generations (NLG), 2019). 
Providing education for refugee children whose schooling has been disrupted is a continuous challenge, and Jordan's Ministry of Education, with its partners, offers various pathways, formal and non-formal, to increase inclusive and equitable access to quality learning for all children and adolescents (Ministry of Education, 2018; NLG, 2018; UNICEF, 2017b). Evidence suggests that Jordan's curriculum relies on traditional methods of learning by memorising textbooks, rather than enabling students to develop analytical and critical thinking skills. It does not sufficiently develop the communication and group working skills needed for students to be successful in the modern world and to enable refugees to become self-sufficient individuals when they reach adulthood (Ministry of Education, 2018; UNICEF, 2017a).

Various efforts are being taken to address these deficits. UNICEF's Hajati cash assistance scheme, an unconditional cash transfer targeting 10,000 families (regardless of nationality but primarily reaching Syrians), promotes education for the most vulnerable children in Jordan, with each eligible child receiving 20 Jordanian dinar (JOD) ( $(22)$ a month during the school term (UNICEF, 2018b). Non-governmental actors are also providing non-formal education, bridging service gaps, to support vulnerable children (including refugee adolescents), often coupled with complementary services such as psychosocial support and life skills (Culbertson at al., 2016). A key example is UNICEF Jordan's Makani ('My place') nonformal education programme, launched in 2015. With non-governmental and community-based partners, UNICEF runs Makani centres across Jordan that provide alternative education alongside life skills training, child protection and psychosocial support, for all vulnerable children and adolescents, regardless of nationality (UNICEF, 2015). The Middle East and North Africa (MENA) Life Skills and Citizenship Education (LSCE) initiative (also launched in 2015) aims to create an enabling environment for better learning in Jordan, and it contributed to the Ministry of Education's adoption of a student-centred approach and introducing activities to develop life skills among public school students (UNICEF, 2018a; Ministry of Education, 2018; UNICEF, 2017a). The Ministry's Education Strategic Plan (ESP) 2018-2022 is linked with Jordan's National Agenda for Human Resource Development and SDG 4. It emphasises modifying the curriculum to include lessons on 'cooperation, teamwork, communication skills, negotiation skills, emotional skills (teaching sympathy and empathy), decision-making skills, critical thinking and problem-solving skills, dealing with others, self-management and anger management'. In 2017, the Nashatati ('My activities') programme was launched in schools, in collaboration with UNICEF and Generations for Peace, to cultivate life skills and social cohesion, involving the most vulnerable children (including Syrian refugees) in after-school activities (UNICEF, 2019b).

\section{Conceptual framework}

The conceptual framework of the Gender and Adolescence: Global Evidence (GAGE) research programme, for which the data that informs this chapter was 
collected, draws on the work of Amartya Sen $(1984,2004)$ and Martha Nussbaum (1997). GAGE identifies six adolescent capability domains: education and learning; health, nutrition and sexual and reproductive health; bodily integrity and freedom from violence; psychosocial wellbeing; voice and agency; and economic empowerment. While this chapter focuses on learning barriers and opportunities for Syrian refugee adolescents in Jordan, our framework is designed to capture the effects of the absence of education or truncated education pathways on other aspects of adolescents' lives, emphasising the need for a holistic approach to education investments. A capabilities approach allows us to examine access to education and learning opportunities as a key step for children and adolescents to develop their full potential and become active agents in choosing their futures. Boni and Gasper (2012) emphasise that a capabilities framing of the right to education goes beyond a focus on retention, graduation and employment rates, highlighting the importance of participation, empowerment and equitable opportunities for students from diverse backgrounds. In this regard, Hart and Brando (2018: 302) also call for a focus on the extent to which educational institutions support learners' capabilities to aspire and in turn 'how effective social and environmental conditions are in supporting the conversion of aspirations into capabilities'. Importantly this can include, as Nussbaum (2004) has underscored, the extent to which efforts are made to tackle the gendered inequities that shape adolescent girls' opportunities to both access education and apply it in their life choices.

With increasing attention to learner-centred approaches to education, there is growing consensus among education scholars that while basic literacy and numeracy are essential skills, children and youth should also have opportunities to develop competencies that will shape their personalities, expand their horizons and prepare them for the transition to adulthood (Chalkiadaki, 2018; Bergin, 2017). Analysts emphasise the importance of education as a platform for new forms of learning to face global challenges or acquire skills needed for the twenty-first century (Scott, 2015). Chalkiadaki’s (2018) systematic review consolidated the competencies from varied typologies of twenty-first-century skills into four categories: (1) personal skills (including self-development creativity, problem-solving and critical thinking, and presence in the globalised environment), (2) social skills (understood as communication and collaboration, cultural awareness and global awareness), (3) information and knowledge (self-learning and information management) and (4) digital literacy.

While some competencies are more relevant in highly resourced and digitally well-connected contexts, many cited competencies are also applicable in low- and middle-income countries (LMICs), including in refugee contexts (Joynes et al., 2019; Kennedy et al., 2014), such as communication, social skills and cognitive skills. As such, strategies of integrating life skills into the curriculum or extracurricular activities and teaching practices, and promoting multiple pathways to learning in formal, non-formal and informal settings, were mentioned during the Brussels Conference in 2017 as key to ensuring that education for all refugee 
children builds skills that will allow them to engage in further learning and work and to contribute to rebuilding their communities and countries (No Lost Generation (NLG), 2018).

Accordingly, this chapter explores adolescents' access to opportunities to acquire academic and non-academic core competencies for the twenty-first century that are also relevant to their situation in a context of displacement. We explore the extent to which formal and non-formal education services support adolescents' aspirations and how their broader social and environmental contexts - including age and gender inequities - facilitate or hinder their ability to acquire these competencies and fulfil their aspirations.

\section{Methods}

This chapter draws on mixed-methods research undertaken by GAGE to explore adolescents' access to learning services and investigate the barriers they face and support they receive to acquire the skills and knowledge needed to realise their full potential in adult life. Specific research instruments were developed to capture vulnerabilities of married girls and young mothers (Jones et al., 2018; Jones et al., 2019a; Jones et al., 2019b). As part of the quantitative survey, GAGE implemented a version of the Annual Status of Education Report (ASER) test of basic numeracy and literacy. ${ }^{2}$ We complemented this with Raven's Coloured Progressive Matrices, which provide a measure of abstract reasoning (measuring observational skills, problem-solving and overall ability to learn). We also used measures of school enrolment (in both formal and non-formal schools), attendance, educational transitions, achievement, educational aspirations and attitudes towards education, including caregivers' support.

Our findings are based on the GAGE baseline quantitative survey and two rounds of qualitative data collection (2018 and 2019). Our sampling frame utilised UNICEF Jordan and UNHCR lists of adolescents in the two GAGE cohorts (10-12 years and 15-17) and was based on household vulnerability, with the sample equally divided by gender and Makani participation. GAGE baseline data was collected between mid-2018 and early 2019 and comprised a quantitative survey ${ }^{3}$ of more than 4,000 adolescents and their caregivers (including more than 3,000 Syrians), and a subsample of 200 early-married adolescents and 400 adolescents with disabilities. The qualitative baseline comprised 394 in-depth individual interviews (IDIs) with vulnerable adolescents and their caregivers; 75 focus group discussions (FGDs) with adolescents, parents and community leaders; and 44 key informant interviews (KIIs) with service providers (formal and non-formal) (see Table 5.1).

Adolescents in GAGE Jordan's sample included vulnerable Syrian refugees in three settings: host communities, informal tented settlements (ITSs) and either Azraq or Zaatari refugee camp, across four governorates: Irbid, Mafraq, Zarqa and Amman (see Figure 5.1). 
TABLE 5.1 Baseline qualitative sample in Jordan

\begin{tabular}{|c|c|c|c|}
\hline \multicolumn{2}{|c|}{ Jordan baseline qualitative sample } & \multirow{2}{*}{$\begin{array}{l}\begin{array}{l}\text { Individual } \\
\text { interviews }\end{array} \\
\mathbf{1 5 0}\end{array}$} & \multirow{2}{*}{$\begin{array}{l}\text { Focus group } \\
\text { discussions }\end{array}$} \\
\hline & Total & & \\
\hline \multirow[t]{3}{*}{ Girls } & Younger & 65 & 7 \\
\hline & Older & 85 & 16 \\
\hline & Total & 100 & 23 \\
\hline \multirow[t]{2}{*}{ Boys } & Younger & 54 & 7 \\
\hline & Older & 46 & 16 \\
\hline Total adolescents & & 250 & 46 \\
\hline \multirow{2}{*}{ Caregivers } & Female caregivers & 65 & 10 \\
\hline & Male caregivers & 35 & 10 \\
\hline Key informants & Community and national level & 44 & 9 \\
\hline \multicolumn{2}{|c|}{ Total caregivers and key informants } & 144 & 29 \\
\hline \multirow[t]{3}{*}{ By vulnerabilities } & Incl. adolescents with disabilities & 60 & - \\
\hline & Incl. married girls & 30 & - \\
\hline & Incl. Syrian adolescents & 177 & 36 \\
\hline \multirow[t]{3}{*}{ By location } & In camp & 125 & 18 \\
\hline & In host communities & 80 & 38 \\
\hline & In informal tented settlements & 45 & 18 \\
\hline
\end{tabular}

\section{Findings}

In line with our capabilities conceptual framing, we now discuss our findings, focusing on four areas: opportunities for Syrian refugees in Jordan to acquire academic and non-academic competencies (including the personal, social, digital and critical reasoning competencies needed for twenty-first-century life), their opportunities to exercise voice and agency within the learning environment, their educational aspirations and the extent to which socioeconomic and environmental factors enable them to realise these aspirations.

\section{Opportunities to achieve academic competencies}

Our findings show that in line with the broader literature, Syrian refugees in Jordan have poor learning outcomes overall, and there is a significant gap between outcomes for Jordanian and Syrian adolescents. Across age groups and genders, only 45 per cent of Syrian adolescents in our sample were able to read a simple story, compared with 55 per cent of vulnerable Jordanians. For math, only 37 per cent of Syrian adolescents were able to perform double-digit subtraction with borrowing, compared to 52 per cent of Jordanians. These outcomes demonstrate that even for adolescents who attended basic primary school, the quality of education offered to Syrian girls and boys does not equip them with basic numeracy and literacy skills; this, in turn, leads adolescents and caregivers to attach little importance to schooling. As the mother of a 14-year-old Syrian boy living in a host community noted: 


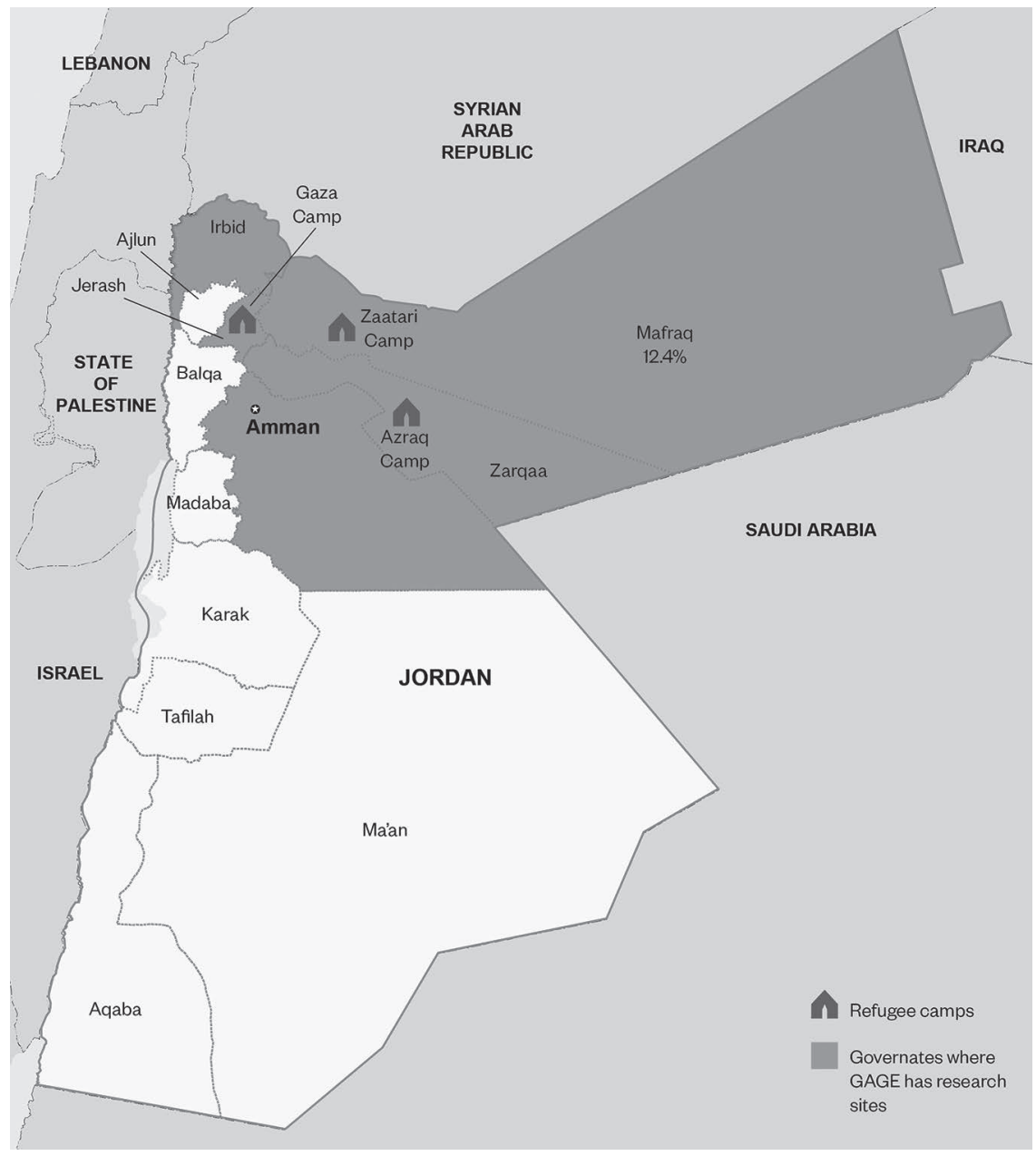

FIGURE 5.1 Map of GAGE research sites in Jordan.

Source: Based on the UNHCR Jordan situational map of Jordan as of 2018 and modified to show GAGE research sites.

Our children are in governmental schools and they do not get any benefit from attending. They have no social skills. I have a son who is in ninth grade, but he does not read and write well.

Our qualitative research also emphasised that adolescents often receive a pass for the next grade without fulfilling learning objectives for the year. A 17-year-old boy from Azraq Camp said:

I'm at a good standard, but they don't ask us to learn things. And they don't give us mid-term exams, just the final exam. We used to have exams eight 
times in Syria - every month, mid-terms and finals. Yes, I will pass easily, and be ineffective in my future. .. I may become a doctor who can't read properly. ... I may become a teacher who doesn't know Arabic grammar.

In Azraq and Zaatari camps, there seem to be differences in the curriculum and teaching approach between schools for boys and girls, with girls having a more comprehensive programme and teachers being more dedicated to their learning. As a father in Zaatari Camp observed:

My son is in tenth grade, and my brother's daughter is also in tenth grade, at the same type of school. When I compared the two, I found that my brother's daughter has three or four lessons extra compared to my son. Girls are in school before them, and there are some extra books for them.

\section{Opportunities to develop core non-academic competencies necessary for twenty-first-century life}

\section{Personal development skills}

Our findings show that overall, vulnerable adolescents in Jordan have limited opportunities to learn personal development skills (such as communication and negotiation) that would help them achieve their full potential. Schools have a narrow focus on academic learning outcomes, and the quality of teaching and pedagogical methods are often lacking, especially in afternoon shifts. The home environment also rarely supports Syrian adolescents to build personal skills, and the hierarchical culture does not support voice and agency for children and adolescents. This is noticeable when looking at the experiences of Syrian adolescent refugees who have had an opportunity to participate in extracurricular activities and alternative learning pathways that allow them to socialise with people outside their families and their peers. Syrian adolescents who participated in UNICEF's Makani programme emphasised how this had helped their personal growth and compared it to formal schooling:

The first aim [in school] is to teach us the books, while Makani centre is different. They allow us to express our opinions and they give us a space for these skills more than the schools. They aim to build the person's personality, then education.... The teachers in school basically don't give us the space to talk... They aim to enter the class, explain the lesson and then they go out of the class.

(Older girl participating in Makani Social Innovation Lab, host community)

Our qualitative findings emphasise that many adolescents, especially girls, lack selfconfidence and have very few opportunities to build their self-worth. This is especially difficult given conservative social norms built on expectations of girls as being 
timid and silent. Girls highlighted that having an opportunity to cooperate with others and do group activities helps them develop their self-esteem, as a 16-yearold Syrian girl from Irbid explained:

The life skills course is about the human soul, one's personality, what can one do. It is about the human itself, their life, what they can do. I benefited from this life skills course as I became more confident in myself. ... I learnt to trust myself, think correctly, and not to rush in speaking.

Our findings also show that adolescents appreciated opportunities to learn more about different scientific disciplines and, in some cases, to propose solutions to small problems in their communities, building their initiative and sense of agency.

\section{Social skills}

Girls and boys both reported that they value Makani centres for providing a space where they feel safe and respected, enabling them to learn and connect with peers something that many girls would not otherwise be able to do. Life skills sessions are appreciated by children of all ages and genders. Girls, in particular, said they feel respected during classes and that they are allowed to discover their talents, connect with friends and develop communication skills. As an older Syrian girl from a host community explained:

They educated us about the dialogue methods and how to talk. As an example: I should know how to talk with a person who is in front of me, whoever they are. Treating a young person is different than the way you treat an old person. At Makani, they educated us how to deal with younger and older persons.

Many girls also mentioned that Makani helped them to discuss topics that are not easy to raise with mothers and other family members and to negotiate on issues that are important to adolescents.

\section{Digital literacy skills}

Adolescents' digital literacy varied, with some demonstrating fairly advanced skills, while others had very basic proficiency, even in using social media. Our findings further highlight that access to the virtual environment and acquisition of digital skills differs by age, gender and location, strongly linked to the family's socioeconomic situation. Girls reported fewer opportunities than boys to use the internet freely, partly due to less access to digital devices overall and partly due to social norms that restrict their use of such devices (for example, boys can go to internet cafes but girls are not allowed to, so boys gain more digital skills). Computers are rarely available at home or in schools, though many adolescents expressed a desire 
to learn and expand their computer skills, recognising it as a vital competency in the modern world. A 16-year-old boy living in Zaatari Camp also emphasised the importance of combining computer skills with learning English, as there is limited software available in Arabic:

If we want to use any programme, we should know English. So, if we don't know, we can ask the teacher [Makani facilitator]. In the past, I felt surprised when I saw the computer and I was not able to turn it on.... Now, I can use it normally. In school, we have a computer book, but there is no computer.

Where adolescents do have internet access, they usually rely on smartphones and use it for entertainment (watching a series or playing games), but also to communicate with peers and family. Some boys mentioned the digital environment as an important source of information and knowledge.

\section{Critical thinking and reasoning skills}

Critical thinking and reasoning skills are key twenty-first-century competencies, but our findings suggest that Syrian adolescents have few opportunities to develop these skills. It is unusual for them to be asked questions - either at home or in school - that would foster reflection and invite them to consider different perspectives in order to solve problems in their lives or plan their futures. This was evident during our interviews, when adolescents demonstrated limited ability to reflect critically on what they were asked; some admitted that the conversation with the researcher was the first time someone invited them to reflect on an issue and share their opinion. Developing these competencies is an important part of the Makani curriculum, as a life skills facilitator from Azraq Camp explained:

Life skills sessions aim to modify thinking, so that it goes in a positive direction. Critical thinking, problem-solving are integrated in lectures and sessions so as to give intellectual autonomy, which is directed towards intellectual independence... stimulate the child and give them the basis for logical thinking, understanding existing possibilities, and guiding thoughts.

Several adolescents who participated in Makani mentioned that they learnt how to prioritise their needs and plans, and how valuable this opportunity was. A 16-yearold Syrian girl from Irbid commented:

We learned from the community innovation programme that we can work on a small skill to be able to solve problems using this newly learnt skill. We should depend on ourselves and correct our mistakes. I also learnt to solve any problem - whatever it is - by using the simplest solutions. I think this will be very useful in my future life. 


\section{Opportunities to exercise voice and agency in the learning process}

A key dimension of a capabilities framing of the right to education relates to opportunities for young people to exercise voice and agency in the learning process. Our findings underscore that - for all students but especially refugees - Jordan's formal school system is neither empowering nor participatory. Many adolescents reported teacher discrimination, indifference and even violence.

\section{Discrimination in the school system}

In host communities, 43 per cent of Syrian adolescents thought that under the double-shift school system, they are treated unequally with Jordanians. Tensions between Syrian and Jordanian students are high and not conductive to learning, as a 12-year-old boy living in Mafraq noted:

In sharing the school there is more attention for Jordanians. This happens for some classes and in some subjects... There is some discrimination and harassment between students.

Conflicts between students often turn violent, and students can experience harassment on the way to school or on school grounds, especially during the break between shifts, as a 13-year-old Syrian boy in a host community described:

Every day there were problems.... Jordanians were returning home at $11 \mathrm{am}$, and we were going to school at 12 noon. .. . The Jordanians were grabbing a Syrian boy, asking him for money, and then they were fighting with each other.

\section{Limited teacher commitment}

Many adolescents noted that discrimination was also reflected in low teacher commitment to support Syrian students in acquiring basic competencies, which was leading to disillusionment with school. Some complained that standards for Syrians in double-shift schools are low, and so students are discouraged from attending, as they feel it is pointless. An 11-year-old boy from Mafraq explained:

Our teacher gave us some questions, then he slept. We were cheating, and some opened the books to look for the answers.... Sometimes the teacher takes the exam sheets home and he answers instead of us. . . He told us to write using the pencil, so that when he finds something wrong, he can erase it. ... Later, the principal wonders how Syrians pass the exams.... There was a guy who cannot read or write, and he got $85 \%$. 
These findings most likely reflect the fact that many teachers assigned to the double-shift classes were either new graduates or brought out of retirement to cover the influx of new refugee students. They may have received little (if any) training on how best to support refugee students; they also complained of more limited resources and access to equipment compared to teachers doing the morning shifts (with mainly Jordanian students) (see Jones, Baird, Małachowska, Kilburn et al., 2019).

\section{Peer and teacher violence}

Our findings also show that violence in school is widespread and usually experienced more by boys.Violence includes peer bullying and harassment, but it is also often perpetrated by teachers: more than half ( 56 per cent) of Syrian boys experienced some form of violence in school compared to 22 per cent of girls, with many boys describing brutal teacher discipline methods. As a 19-year-old girl living in an ITS recounted (her younger sibling's experience):

The principal once beat up a very young child. He was not even in the first grade, but in pre-school. He was beaten because he cried when his father left him. I mean, it is his first time to go to school! The principal did that in front of everyone. My brother has been scared ever since. He is only in the third grade and the teacher once told him and his classmates that if they do not memorise the lesson by the next day, he would make their faces bleed. Now, when my brother sleeps, he sees that teacher in his nightmares.

Violence is not, however, exclusive to Syrian students, with 64 per cent of Jordanian boys and 33 per cent of girls also experiencing violence in school. Our qualitative findings point to corporal punishment being one of the main reasons for boys dropping out or losing interest in schooling, as a 16-year-old boy from Zaatari Camp explained:

He [the teacher] used to hit my head against the wall and beat me.... He also used to beat me with a stick. When he started to hit me, I stopped going to school.

Somewhat surprisingly, most adolescents, despite high levels of violence, reported feeling safe in school (93 per cent of boys and 95 per cent of girls), which suggests that corporal punishment and verbal abuse have become normalised.

\section{Opportunities to develop the capacity to aspire through education}

The capacity to aspire through education is increasingly recognised as a critical component of educational achievements and broader wellbeing. Our research 
found that educational aspirations among the Syrian adolescents in our sample are generally high, but lower than their Jordanian counterparts - 79 per cent of Syrian boys and 82 per cent of girls aspire to complete at least secondary education, compared to 91 per cent and 93 per cent for Jordanian adolescent boys and girls respectively. Moreover, there are significant differences between locations, with adolescents in ITSs demonstrating lower aspirations to complete at least secondary education than those in camps and host communities (60 per cent in ITS, 80 per cent in camps and 86 per cent in host communities). Notably, even older married girls demonstrated high educational aspirations, with 70 per cent wanting to complete at least some secondary education compared to 86 per cent of never-married girls.

Our qualitative research emphasised that out-of-school adolescents, also in the most disadvantaged communities, wish they could continue their education. An older out-of-school girl in an ITS explained:

All of us want to go back to school. We want to convince our parents to send us to school. This is our ambition.

Yet this strong desire to return to education is not reflected in reality, as adolescents have limited opportunities for achieving their aspirations. Overall, 71 per cent of Syrian adolescents in our sample are enrolled in formal school (compared to 89 per cent for Jordanians), and 16 per cent attend non-formal education classes; adolescents in ITSs are least likely to attend any type of schooling (44 per cent enrolled in school and 15 per cent in alternative education programmes). However, in line with existent evidence, enrolment rates are much higher among younger Syrian adolescents compared to their older peers, and older girls often have opportunities for learning curtailed once they have gained basic literacy and numeracy skills:

They tell me that I can write and read, so no need for school.

(17-year-old out-of-school girl, living in an ITS near Amman)

Early-married girls in our sample are largely excluded from education, with only 9 per cent enrolled in school and 5 per cent having access to non-formal classes. Many factors influence these variations in access to education, discussed in the following.

\section{Social and environmental conditions needed to translate educational aspirations into freedoms}

Even if refugee adolescents have the capacity to aspire, a capabilities framing of the right to education emphasises the importance of investments to create a broader social and economic environment conducive to realising those rights. Our findings underscore that for many Syrian refugees in Jordan (and arguably especially for girls), these conditions are not being met. Here, we discuss the key barriers that 
hinder the fulfilment of adolescent aspirations for higher education and related employment.

\section{Limited parental commitment to education}

Although parents' educational aspirations for their adolescent children are generally very high (95 per cent of Syrian caregivers aspire for their child to complete at least secondary education), this is rarely translated into practical support. It is also strongly influenced by gender norms, with girls expected to do more household chores than boys. Our survey findings show that on average, girls spend more than an hour a day cleaning, cooking and doing other duties, often at the cost of studying time, while boys spend just 15 minutes, giving them more time for study and play. This burden is higher for adolescents in ITSs and causes frustration for some girls, as an 11-year-old from Irbid explained:

When I wash dishes, I asked him [her brother] for help, he refused and shouted at me. I do it because I am the only girl in the house. He is playing on the phone only.

Gender norms play a key role in allocation of household duties and prioritising household responsibilities at the expense of education - 35 per cent of Syrian adolescents in our sample believe that girls are only allowed to go to school if they are not needed at home, but in ITSs this rose to 61 per cent. A 12-year-old girl living in an ITS explains the burdens put on her:

I stay at home because my father's sick and he can't take care of them [her siblings] by himself and my mother works in the fields. He only lets me go to school during winter. . because when it rains, my mother stays at home and watches my siblings, then I'm able to go to school.

Married girls who have been withdrawn from school have to do household chores full-time. A 17-year-old married girl from Azraq Camp noted:

I lived at my husband's family house and I was responsible for house duties there: cleaning, cooking and anything else.

\section{Economic constraints}

In line with the broader literature, economic hardships among Syrian refugee families were found to be a major factor in adolescents dropping out of school. While girls usually stay at home to do housework, adolescent boys tend to do low-paid jobs, sometimes working long hours and in exploitative conditions. In 
female-headed households and where caregivers were constrained by illness, boys often became the breadwinner, as a 12-year-old boy from an ITS in Irbid noted:

We need money and we are $1,900 \mathrm{JOD}\left(\mathcal{K}^{2}, 050\right)$ in debt to my father's cousin. ... My father has problems with his back and he couldn't work any longer, so he borrowed the money for our expenses. After that, we all needed to start working.

Our survey found that, among the older cohort, 66 per cent of boys and 12 per cent of girls had done some form of paid work in the year prior to the interview, and adolescents in ITSs (boys and girls, younger and older) are more likely to work. As a 17-year-old boy in an ITS, with a hearing impairment, explained:

I work on a farm, but it is not enough for family expenses. My brother and I work and sometimes my younger brother helps too.

Adolescents who engage in child labour either drop out of school or struggle to combine the two, as a 13-year-old girl living in a host community reported (she spends three days a week working, and the rest of the time she tries to focus on schooling):

I like school and I like to go and study. Though I have a lot of work pressure, sometimes I leave work and go to school. It depends - sometimes I say my school is more important and sometimes I say the work is more important.

Combining work and learning is even harder for adolescents who work seasonally, as they can spend months out of school; re-enrolment is dependent on the school principal agreeing to take them back and on their parents' motivation. For some adolescents, long absence results in expulsion, in which case they rarely seek catchup education due to distance and low priority assigned to children's education - by parents and adolescents alike. Economic pressures force adolescents to prioritise low-skilled work at the expense of education, which, in turn, deprives them of opportunities to develop and acquire skills and qualifications needed to obtain better employment in future. At the same, with limitations on work permits for Syrians in Jordan, many households have difficulties finding employment, which demotivates youth even further and prevents young people making an effort to continue their studies, as a 17-year-old girl living in Azraq Camp, who dropped out of school after ninth grade, noted:

In Syria, ninth grade certificate is nothing. Here, (in Jordan), even if one has a certificate from a university, he might be employed, but it is not guaranteed to be in a good position. Like, you might find a teacher who is employed in the sanitation centre. 


\section{Limited voice and agency}

Our findings also highlight the limited voice and agency that adolescents, particularly girls, are able to exercise. Overall, adolescents have limited decision-making power within the family, so they cannot influence decisions about their lives, including education. When asked about their perceptions of having some say in household decisions, adolescents demonstrated a medium level of influence on decision-making (a mean of 5 on an index scored $0-8$ ). However, there were important gender differences: girls have less say than boys, and while decision-making power increases with age for girls and boys alike, the increase is not as significant for older girls. This is not surprising when we compare attitudes towards decisionmaking -78 per cent of Syrian girls and 88 per cent of boys think that most people in their community expect men to have the final say in family decisions.

These perceptions are reflected in adolescents' realities, as a 14-year-old girl from Zaatari Camp explained:

There are some things women just can't do. For example, if a girl wants to drink a glass of water, or if her eyes get ill, she should ask her father or her husband's brother. [They] decide for her, and say 'this is it, you can't wear it, you can't go, can't put henna' - everything is forbidden. Manicure is forbidden, everything is forbidden for her.

The family is a place where adolescents could learn to voice their opinions and express their views, but they report that their opinions are often not valued. Married girls who aspire to continue their education do not have the skills needed to convince their families, and their wishes are not taken into account. As a 17-yearold married girl in Azraq camp noted:

I was attending school but now I'm not. . . I would like to complete my education, but my husband refuses. Last thing he said, choose whether it is me or the school! ... Then I insisted and there were a lot of problems.

Restricted mobility is also a challenge, especially for girls. Only 66 per cent of Syrian girls leave their homes every day (compared to 87 per cent of boys). Moreover, their mobility decreases with age, so older girls have very limited opportunities to socialise with peers, restricted access to education and no opportunities to participate in community life. While girls' mobility is restricted in all locations, this was found to be especially the case in ITSs, where control over girls' movement and interactions with others is even more strict, as this 15-year-old girl described:

Young men can go out (of the settlement) freely and deal with a lot of people and learn to talk to other people. It is different for girls - they can't go out of the house and they do not know how to deal with people. Parents are afraid for girls, but at the same time parents should encourage their girls to deal with others. 
Restrictions on girls' mobility are strongly embedded in gender norms linked to upholding family honour. A social worker working with Syrians in ITSs explained:

There are more spaces available for the males. . because of the traditional thinking and the parents' attitudes, which is very strong in the community. These issues are also connected with honour and shame for the family; there is no shame for boys if they do what they want. There is even protection for the boy, while in the case of a girl, her reputation is affected; these are the social norms here.

Family restrictions on girls' mobility are one of the main barriers to accessing education and other services, particularly in camps, as a Makani facilitator in Zaatari camp reported:

All the age groups come here, but families prevent their girls to come here after a specific age. These girls are the adolescents who are at puberty stage. Usually they stop coming when they turn 14. I follow up and ask why she didn't come, and typically she answers that her father didn't allow her to come or the boys harass her.

Girls' behaviours, especially as they get older, are strictly monitored by parents and other family members, and there is a strong social pressure to prevent girls from doing anything that would endanger family honour - for example, interacting with boys; having access to, and using, digital devices; or wearing inappropriate clothing. These social pressures are enforced and also internalised. It is also common to shift responsibility for undesirable behaviours from boys to girls, even if something is beyond a girl's control, as an older Syrian girl in an ITS near Amman noted:

When a girl goes out to go to school, boys keep harassing her.... It is because of this issue that we are forced to leave school.... And so the parents, and other people will say bad things about her. So we must not go to school and not go to the places that we want to go to, because of this.

Restrictions in accessing the internet and social media are strongly skewed towards girls and further limit girls' ability to learn and interact with peers. Our survey found that only 26 per cent of older girls (compared to 47 per cent of older boys) own a phone, and 41 per cent had ever used the internet (compared to 54 per cent of boys).

\section{Norms about age at marriage}

Child marriage is common among Syrian refugees and is often the reason for girls leaving school. Girls either drop out in anticipation of being married or at the time of marriage. Of our sample, 62 per cent of Syrian boys and 70 per cent of girls admitted that in their community girls are expected to get married before the 
legal age (18 years), and among girls who are married, only 9 per cent were able to continue their education. Our qualitative findings show that the reasons for child marriage are often determined by tradition and social norms, which combine with economic hardship, social pressures, no viable alternative pathways for girls, lack of conviction of the importance of education, as well as a desire to control girls. As a teacher from Amman explained:

Syrian girls marry early and I often hear girls talking about their sisters getting married at 16 years.... I noticed that one of my students stopped coming to school. It turned out her father doesn't accept a girl going to school beyond sixth grade. ... The culture here. . the poverty, early marriage, the low education level of parents - this reflects on the girls.

The decision to pull girls out of school in preparation for marriage is not always taken unilaterally by parents; many adolescent girls also aspire to marry, given the social prestige associated with marriage and so are willing to leave school if it adds to their desirability for marriage, even if the girl's parents oppose it. As the mother of a married girl in Azraq Camp commented:

My other daughter was attending ninth grade when a man asked to marry her and she got engaged in the middle of the school year. So she dropped out. I tried hard to make her stay at school; I wanted her to finish her education. I asked her to forget about marriage... I told her that I will take off her ring and keep it aside. . . She refused.

\section{Conclusions}

Notwithstanding international and national commitments to ensuring quality education for all young people, including those affected by displacement, our findings highlight that a decade after the onset of the Syrian refugee crisis, many Syrian adolescents living in Jordan in camps and host communities alike face significant and multidimensional barriers to realising their full education and learning capabilities. These findings are particularly sobering in terms of global debates around 'leaving no generation behind', given that the regulations around refugees' access to schooling in Jordan are relatively favourable (when compared to contexts like Bangladesh, for example, where the Rohingya are barred from the national education system) (Guglielmi et al., 2020).

The quality of teaching and the broader school environment - not least teacher attitudes and institutionalised violence - also prevent many refugee students attaining core academic competencies. Moreover, the formal curriculum does not support students to develop the non-academic competencies (including personal development, social skills, digital skills, and critical thinking and reasoning skills) needed for twenty-first-century life. There are exceptions - most notably UNICEF Jordan's Makani non-formal education initiative (albeit uptake of such programmes by older refugee adolescents is relatively limited). 
These service deficits aside, our data shows that many refugee adolescents still aspire to attain at least some secondary education and that this is echoed in parental aspirations for their adolescent children. However, our findings highlight intersecting challenges in the broader enabling environment in translating these educational aspirations into reality - especially for girls and for adolescents in ITSs. Challenges include: limited practical support from parents, expectations that adolescent girls will support domestic tasks and boys contribute to fragile household incomes through involvement in child work, adolescents' limited voice and agency in household decision-making, and discriminatory conservative gender norms that constrain girls' mobility, and put them at risk of child marriage at the cost of their education.

The policy implications of these findings point to an urgent need to mainstream a capabilities framing of the right to education. This would entail moving beyond a narrow focus on enrolment and retention, to expand investments within the formal education system to deliver non-academic competencies (harnessing promising practices from non-formal programmes for refugee adolescents) at scale. Given the traumatic disruption of their childhood and the immense challenges of forging a future within the context of displacement, acquiring twenty-first-century skills is especially important for refugee populations and must be seen as an integral part of the right to education, rather than as optional. A capabilities framing, with its emphasis on supporting young people to meaningfully avail themselves of educational opportunities, also necessitates improving training of teachers in positive disciplinary approaches and in non-discriminatory pedagogy for refugee populations. It also underscores the importance of investing in community outreach and awareness raising on gender equity; tackling discriminatory attitudes and practices towards girls that undermine their right to education; and investing in social protection for the most vulnerable refugee households to address the economic barriers to sending their children to school.

\section{Notes}

1 Service cards are very difficult to obtain for many Syrian families who left the camps without being sponsored by Jordanian citizens.

2 The reading portion of the ASER tests whether the respondent can read (in Arabic) at the following levels: story, paragraph, word, letter or nothing. The math portion of the ASER tests whether the respondent can do subtraction, addition, recognize double-digit numbers, recognize single digit numbers or do nothing.

3 Survey instruments for adolescents and caregivers are publicly available and can be found here: www.gage.odi.org/publication/jordan-baseline-survey-2017-18/

\section{References}

Abu Hamad, B., Jones, N., Samuels, F., Gercama, I., Presler-Marshall, E., with, Plank, G., Essaid, A., Ebbini, S., Odeh, K. B., Bazadough, D., Abu Taleb, H., Al Amayreh, H., and Sadji, J. (2017) A promise of tomorrow: the effects of UNHCR and UNICEF cash assistance on Syrian refugees in Jordan. London: Overseas Development Institute. 
Bergin,C.(2017) Promising practices in refugee education:synthesis report.London:Save the Children. Available at: https://resourcecentre.savethechildren.net/library/promising-practicesrefugee-education-synthesis-report

Boni, A., and Gasper, D. (2012) Rethinking the quality of Universities: how can human development thinking contribute? Journal of Human Development and Capabilities 13(3): 451-470.

Chalkiadaki,A. (2018) A systematic literature review of 21st century skills and competencies in primary education. International Journal of Instruction 11(3): 1-16.

Culbertson, S., Ling, T., Henham, M-L., Corbett, J., Karam, R., Pankowska, P., Saunders, C. L., Bellasio, J., and Baruch, B. (2016) Evaluation of the emergency education response for Syrian refugee children and host communities in Jordan. New York: UNICEF. Available at: www.rand. org/pubs/research_reports/RR1203.html

Department of Statistics and ICF. (2019) Jordan population and family health survey 2017-18. Amman, Jordan, and Rockville, MD, USA: Department of Statistics and ICF. Available at: https://dhsprogram.com/pubs/pdf/FR346/FR346.pdf

Early Grade Reading and Mathematics Initiative (RAMP). (2018) Lot quality assurance sampling assessment. Available at: https://ierc-publicfiles.s3.amazonaws.com/public/ resources/Jordan\%20RAMP\%20LQAS\%20Summary\%20Report\%20FINAL.pdf

Guglielmi, S., Jones, N., Muz, J., Baird, S., Mitu, K., and Uddin, M. A. (2020) 'I don't have any aspiration because I couldn't study': exploring the educational barriers facing adolescents in Cox's Bazar. London: Gender and Adolescence: Global Evidence.

Hart, C. S., and Brando, N. (2018) A capability approach to children's well-being, agency and participatory rights in education. European Journal of Education 53:293-309. https://doi. org/10.1111/ejed.12284

Human Rights Watch. (2016) 'We're afraid for their future': barriers to education for Syrian refugee children in Jordan. Human Rights Watch website. Available at: www. hrw.org/report/2016/08/16/were-afraid-their-future/barriers-education-syrianrefugee-children-jordan\#_ftn5

Human Rights Watch. (2020) 'I want to continue to study': barriers to secondary education for Syrian refugee children in Jordan. Human Rights Watch website. Available at: www. hrw.org/report/2020/06/26/i-want-continue-study/barriers-secondary-educationsyrian-refugee-children-jordan

Jones, N., Baird, S., Presler-Marshall, E., Małachowska, A., Kilburn, K., Abu Hamad, B., Essaid, A., Amaireh, W., Sajdi, J., Banioweda, K., Alabbadi, T., Alheiwidi, S., Ashareef, Q., Altal, S., Kharabsheh, W., Abu Taleb, H., Abu Azzam, M., and Abu Hammad, B. (2019) Adolescent well-being in Jordan: exploring gendered capabilities, contexts and change strategies. A synthesis report on GAGE Jordan baseline findings. London: Gender and Adolescence: Global Evidence.

Jones, N., Camfield, L., Coast, E., Samuels, F., Hamad, B.A.,Yadete, W., Amayreh, W., Odeh, K. B., Sajdi,J., Rashid, S., Sultan, M., Małachowska,A., and Presler-Marshall,E. (2018) GAGE baseline qualitative research tools. London: Gender and Adolescence: Global Evidence.

Jones, N., Presler-Marshall, E., Małachowska, A., Jones, E., Sajdi, J., Banioweda, K., Yadete, W., Emirie, G., and Gezahegne, K. (2019a) Qualitative research toolkit to explore child marriage dynamics and how to fast-track prevention. London: Gender and Adolescence: Global Evidence.

Jones, N., Presler-Marshall, E., Małachowska, A., Jones, E., Sajdi, J., Banioweda, K., Yadete, W., Gezahegne, K., and Tilahun, K. (2019b) Qualitative research toolkit: GAGE's approach to researching with adolescents. London: Gender and Adolescence: Global Evidence.

Joynes, C., Rossignoli, S., and Fenyiwa Amonoo-Kuofi, E. (2019) 21st century skills: evidence of issues in definition, demand and delivery for development contexts. K4D Helpdesk Report. 
Brighton, UK: Institute of Development Studies. Available at: https://assets.publishing. service.gov.uk/media/5d71187ce5274a097c07b985/21st_century.pdf

Kennedy, F., Pearson, D., Brett-Taylor, L., and Talreja, V. (2014) The Life Skills Assessment Scale: measuring life skills of disadvantaged children in the developing world. Social Behaviour and Personality 42(2): 197-210. Available at: www.sbpjournal.com/index.php/ $\mathrm{sbp} / \mathrm{article} / \mathrm{view} / 3518 / 0$

Ministry of Education. (2018) Education strategic plan 2018-2022. Amman: The Hashemite Kingdom of Jordan, Ministry of Education.Available at: www.unesco.org/new/fileadmin/ MULTIMEDIA/FIELD/Amman/pdf/ESP_English.pdf

No Lost Generation NLG. (2018) We made a promise: ensuring learning pathways and protection for Syrian children and youth: full report. NLG website. Available at: https:// reliefweb.int/sites/reliefweb.int/files/resources/Brussels $\% 20$ conference $\% 20$ education\%20report.compressed.pdf

No Lost Generation NLG. (2019) Investing in the future: protection and learning for all Syrian children and youth. NLG website. Available at: www.nolostgeneration.org/sites/ default/files/webform/contribute_a_resource_to_nlg/9466/190227_brussels_conference_report_2019_lo_res_pdf

Nussbaum, M. (1997) Capabilities and human rights. Fordham L. Rev. 66(2): 273.

Nussbaum, M. (2004) Beyond the social contract: capabilities and global justice. An Olaf Palme lecture, delivered in Oxford on 19 June 2003. Oxford Development Studies 32(1): 3-18.

OECD. (2019) Jordan: student performance (PISA 2018). OECD website. Available at: http:// gpseducation.oecd.org/CountryProfile?primaryCountry=JOR\&treshold=10\&topic $=$ PI

Scott, C. L. S. (2015) The futures of learning 2: what kind of learning for the 21st century? ERF Working Paper No. 14. Paris: UNESCO Education Research and Foresight. Available at: https://unesdoc.unesco.org/ark:/48223/pf0000242996

Sen, A. K. (1984) Commodities and capabilities. Oxford: Oxford University Press.

Sen, A. K. (2004) Capabilities, lists, and public reason: continuing the conversation. Feminist Economics 10(3): 77-80.

United Nations. (2020) The Sustainable Development Goals report 2020. New York: United Nations. Available at: https://unstats.un.org/sdgs/report/2020/The-Sustainable-DevelopmentGoals-Report-2020.pdf

UNICEF. (2015) Makani brief. Amman, Jordan. Available at: https://data2.unhcr.org/en/ documents/details/45990

UNICEF. (2017a) Reimagining life skills and citizenship education in the Middle East and North Africa: afour-dimensional and systems approach to 21stcentury skills:conceptual and programmaticframework. Amman, Jordan: UNICEF MENA Regional Office. Available at: www.unicef.org/mena/ reports/reimagining-life-skills-and-citizenship-education-middle-east-and-north-africa

UNICEF. (2017b) Analytical mapping of the life skills and citizenship education in MENA.Amman, Jordan: UNICEF Middle East and North Africa Regional Office. Available at: www. unicef.org/mena/sites/unicef.org.mena/files/2019-11/Analytical\%20Mapping\%20 of $\% 20$ the $\% 20$ LSCE $\% 20$ in $\% 20$ MENA_EN.pdf

UNICEF. (2018a) A new learning agenda for the realization of SDG 4 in MENA. Available at: www.unicef.org/mena/sites/unicef.org.mena/files/2019-11/Operationalization\%20 of $\% 20$ LSCE\%20in\%20Jordan.pdf

UNICEF. (2018b) My needs, our future: Hajati cash transfer post distribution monitoring report. Available at: www.unicef.org/jordan/sites/unicef.org.jordan/files/2018-11/ HajatiPDM-Aug2018_UNICEFJoweb\%20\%281\%29.pdf

UNICEF. (2019a) Jordan country programme 2018-2022. Amman, Jordan: UNICEF Jordan. Available at: www.unicef.org/jordan/media/371/file/Jordan-Reports.pdf 
UNICEF. (2019b) Every child learns: UNICEF education strategy 2019-2030. Amman, Jordan: UNICEF Jordan. Available at: www.unicef.org/media/63031/file/EdStrategy2019-2030-CountrySolution-Jordan.pdf

United Nations Educational, Scientific and Cultural Organization (UNESCO). (2016) UNESCO's education response to the Syria crisis: towards bridging the humanitariandevelopment divide. Available at: https://unesdoc.unesco.org/ark:/48223/pf0000246279

United Nations General Assembly. (2015) Transforming our world: the 2030 Agenda for Sustainable Development. Resolution adopted by the General Assembly on 25 September 2015. New York. Available at: www.un.org/en/development/desa/population/migration/ generalassembly/docs/globalcompact/A_RES_70_1_E.pdf

United Nations General Assembly. (2016) Resolution adopted by the General Assembly on 19 September 2016. New York. Available at: www.un.org/en/ga/search/view_doc. asp?symbol=A/RES/71/1

United Nations High Commissioner for Refugees (UNHCR). (2017a) UNHCR and the 2030 Agenda Sustainable Development Goals. Available at: www.refworld.org/ docid/59db4b224.html

UNHCR. (2017b) 3RP: regional refugee \& resilience plan in response to the Syria crisis. 2017 progress report. Available at: https://reliefweb.int/sites/reliefweb.int/files/resources/3RPProgress-Report-17102017-final.pdf

UNHCR. (2018) Turn the tide: refugee education in crisis. Geneva: UNHCR. Available at: www. unhcr.org/5b852f8e4.pdf

UNHCR.(2019a)UNHCRJordanFactsheetOctober2019[Factsheet].Availableat:file:///C:/ Users/agnie/Downloads/FINAL_UNHCR\%20Jordan\%20Fact $\% 20$ Sheet $\% 20$ October\%202019.pdf

UNHCR. (2019b) Refugee education in crisis: more than half of the world's school-age refugee children do not get an education. Available at: www.unhcr.org/steppingup/wpcontent/uploads/sites/76/2019/09/Education-Report-2019-Final-web-9.pdf

Younes, M., and Morrice, L. (2019) Summary of challenges relevant to refugees' education in Jordan. Brighton, UK: Centre for International Education and Development, University of Sussex. Available at: http://sro.sussex.ac.uk/id/eprint/85443/1/_smbhome.uscs. susx.ac.uk_dm50_Desktop_The\%20Education\%20of\%20Syrian\%20Refugees\%20in $\% 20$ Jordan.pdf 